\title{
KOMPETENSI PROFESIONAL GURU SOSIOLOGI SMA NEGERI KOTA BANDUNG
}

\author{
'Syaifullah Syam, ${ }^{2}$ Yadi Ruyadi, ${ }^{3}$ Lisda Apriyani \\ ${ }^{1}$ Dosen Prodi Pendidikan Sosiologi FPIPS Universitas Pendidikan Indonesia \\ ${ }^{2}$ Dosen Prodi Pendidikan Sosiologi FPIPS Universitas Pendidikan Indonesia \\ ${ }^{3}$ Universitas Pendidikan Indonesia \\ Email : syaifulsyam@upi.edu
}

\begin{abstract}
ABSTRAK
Saat ini tidak semua guru mengampu mata pelajaran yang sesuai dengan latar belakang pendidikannya. Salah satunya adalah guru mata pelajaran sosiologi di sekolah menengah atas negeri di Kota Bandung. $\mathrm{Hal}$ ini tentunya akan berpengaruh terhadap kinerja guru yang dituntut untuk memiliki kompetensi yang mumpuni. Pada dasarnya setiap guru memiliki kompetensi profesional yang berbeda sejalan dengan pengalaman dan kemampuan yang berbeda pula. Penelitian ini melihat penguasaan materi sosiologi oleh guru sosiologi termasuk kedalam kategori menguasai materi, kemampuan penguasaan kompetensi dasar guru sosiologi SMA Negeri di Kota Bandung berada pada kategori menguasai kompetensi dasar, kemampuan pengembangan materi sosiologi secara kreatif guru sosiologi SMA Negeri di Kota Bandung berada pada kategori sangat mengembangkan materi sosologi secara kreatif, dan pemanfaatan teknologi, informasi dan komunikasi dalam pembelajaran sosiologi guru sosiologi SMA Negeri di Kota Bandung berada pada kategori memanfaatkan teknologi, informasi dan komunikasi.
\end{abstract}

Kata kunci : Guru, Kompetensi profesional, Sosiologi.

\section{PENDAHULUAN}

Pendidikan dewasa ini menjadi salah satu kebutuhan pokok yang tidak bisa disepelekan lagi. Profesionalisme dari para pendidik beserta stakeholder pendidikan menjadi sangat penting saat ini pendidikan disoroti sebab menjadi salah satu dasar dalam pembentukan karakter bangsa.

Sejalan dengan Undang-undang No. 20 Tahun 2003 pasal (3) tentang Sistem Pendidikan Nasional (Sisdiknas) menyebutkan bahwa tujuan pendidikan adalah mengembangkan potensi peserta didik agar menjadi manusia bertakwa kepada Tuhan Yang Maha Esa, berakhlak mulia, sehat, berilmu, cakap, kreatif, mandiri dan menjadi warga negara yang demokratis serta bertanggung jawab.

Melihat tujuan pendidikan nasional dapat dikatakan bahwa pendidikan merupakan sebuah usaha yang dilakukan dengan terencana untuk membangun peserta didik menjadi manusia yang lebih baik, pendidikan sendiri memiliki peran yang 
sangat utama dalam membangun suatu bangsa dalam menghadapi segala perubahan kondisi sosial dan budaya yang terjadi saat ini. Pendidikan di Indonesia dapat ditempuh dengan dua jalur yakni pendidikan formal yang diselenggarakan oleh lembaga pendidikan seperti sekolah dan pendidikan nonformal yang diselenggarakan oleh lembaga di luar sekolah seperti bimbingan belajar. Pelaksanaan pendidikan formal dilakukan secara testruktur oleh guru dan siswa dengan proses belajar mengajar. Usman (1996, hlm 4) mengemukakan bahwa "Proses belajar mengajar merupakan proses yang mengandung serangkaian perbuatan guru dan siswa atas dasar hubungan timbal balik yang berlangsung dalam situasi edukatif untuk mencapai tujuan tertentu."

Untuk mewujudkan proses belajar mengajar yang efektif dan mencapai tujuan pembelajaran maka diperlukan seorang guru yang berkompeten dalam bidangnya. Seorang guru yang profesional harus memiliki kemampuan dalam mengelola kelas dengan baik "guru tidak hanya berperan sebagai model atau teladan bagi siswa, tetapi juga sebagai pengelola pembelajaran (manager of learning)" (Sanjaya, 2006, hIm 52).

Guru merupakan seorang pendidik yang memiliki kompetensi atau kemampuan yang berbeda dengan profesi lainnya dan memiliki tanggung jawab dalam mendidik, membimbing dan juga mengarahkan peserta didik untuk mencapai suatu tujuan pendidikan. Dalam sebuah pembelajaran guru memiliki peran utama atau sebagai ujung tombak dalam terlaksananya pendidikan formal sehingga seorang guru dituntut untuk dapat mengelola kelas agar menjadikan suasana belajar aktif dan juga kondusif, oleh karena itu keberhasilan sebuah pembelajaran ditentukan oleh kualitas dan kemampuan guru dalam mengelola kelas.

Guru-guru dalam tingkatantingkatan yang berbeda akan menerima pendidikan yang berbeda pula, Maka dari itu profesionalisme seorang guru sangat dituntut untuk mencapai tujuan dari pendidikan. Selanjutnya, guru-guru di sekolah yang mengampu suatu mata pelajaran alangkah lebih baik jika memiliki latar belakang pendidikan yang sama dengan mata pelajaran yang diampunya.

Setiap guru dalam mata pelajaran yang berbeda tentu akan memiliki kemampuan yang berbeda juga, sehingga dalam hal penguasaan materi, mengelola kelas, interaksi dalam pebelajaran serta pemanfaatan media dan akan berbeda juga. Saat ini tidak semua guru mengampu mata pelajaran yang sesuai dengan latar belakang pendidikannya. Salah satunya adalah guru mata pelajaran sosiologi di sekolah menengah atas negeri di Kota Bandung.

Guru mata pelajaran sosiologi di Kota Bandung saat ini mayoritas bukan berasal dari latar belakang pendidikan sosiologi, melainkan berasal dari latar belakang pendidikan jurusan yang lain. Hal tersebut menunjukkan bahwa terjadinya missmatch atau ketidaksesuaian antara latar belakang pendidikan guru dengan mata 
pelajaran yang diampunya, terjadinya ketidaksesuaian tersebut berdampak pada terjadinya proses pembelajaran yang kurang menarik, di lapangan pembelajaran sosiologi hanya dilakukan di dalam kelas dan materi disampaikan melalui metode ceramah sehingga pembelajaran lebih monoton, membosankan dan kurang menarik hasrat belajar siswa.

Pembelajaran sosiologi memberikan pemahaman mengenai fenomena kehidupan yang terjadi di masyarakat, materi pembelajaran sosiologi mencakup konsep dasar, pendekatan, metode dan teknik analisis dalam mengkaji berbagai fenomena dan masalah yang terjadi di masyarakat, sehingga dalam pembelajaran seharusnya tidak hanya dilakukan di dalam kelas saja. Masyarakat dan lingkungannya merupakan laboraturium dari sosiologi itu sendiri, sehingga siswa seharusnya dapat belajar secara faktual dan terjun langsung ke masyarakat.

Oleh sebab itu, materi yang dikuasai oleh guru baiknya berdasarkan apa yang buku tuliskan, artinya materi yang diberikan sesuai dengan buku padahal seharusnya materi dan informasi digali dan didapat secara langsung dari keadaan atau kondisi faktual masyarakat sehingga siswa dapat langsung mengaplikasikan teori yang didapatnya.

Oleh karena itu, mengajarkan pelajaran sosiologi dibutuhkan seorang guru yang betul-betul menguasai materi pelajaran dan guru yang memiliki cara mengajar yang tidak monoton karena sosiologi akan selalu berhubungan dengan fenomena yang sedang terjadi di masyarakat yang akan dikaitkan dengan konsep pembelajaran. Daya serap siswa terhadap pembelajaran sosiologi sendiri masih rendah, hal tersebut dipengaruhi oleh minat siswa terhadap mata pelajaran sosiologi dan pembelajaran sosiologi yang salah satunya dipengaruhi oleh faktor guru, yaitu guru yang kurang menguasai bahan ajar. Samana (1994, hlm 18) mengemukakan bahwa "Guru yang baik harus menguasai bahan ajar secara mendalam, berstruktur dan bermakna agar dapat mengarahkan serta membimbing belajar siswa secara bermotivasi dan benar, guru dituntut untuk menguasai bahan ajar pokok dan bahan ajar penunjang".

Seorang guru yang profesional tentunya harus memiliki kompetensi yang mumpuni, diantaranya : kompetensi pedagogik atau kemampuan guru dalam pengelolaan pendidikan peserta didik, kompetensi sosial atau kemampuan seorang guru dalam lingkungan sosialnya, kompetensi profesional atau kemampuan guru dalam meliputi penguasaan bahan ajar dan metodenya, rasa tanggung jawab dan rasa kebersamaan dengan sesama guru dan kompetensi kepribadian atau kemampuan seorang guru dalam memiliki kepribadian yang baik. Guru yang menguasai kompetensi profesional dengan baik maka akan meningkatkan kualitas guru tersebut dalam mengajar. Namun pada dasarnya setiap guru memiliki kompetensi profesional yang berbeda sejalan dengan pengalaman dan kemampuan yang berbeda pula.

Berdasarkan latar belakang diatas, penulis tertarik untuk 
mengangkat masalah mengenai berbedanya kompetensi profesional guru sosiologi di SMA Negeri Kota Bandung. Berdasarkan beberapa fenomena diatas maka penulis akan melakukan penelitian yang berjudul

\section{"Kompetensi Profesional Guru Sosiologi SMA Negeri Kota Bandung".}

\section{METODE}

Penelitian ini menggunakan pendekatan kuantitatif dengan metode deskriptif, metode deskriptif digunakan karena adanya variabel yang akan ditelaah serta tujuannya untuk menyajikan gambaran yang terstruktur, faktual, dan akurat mengenai faktafakta serta hubungan antar variabel yang diteliti. Adapun menurut Sugiyono (2013, hlm. 147) yang dimaksud dengan metode analisis deskriptif adalah "Metode analisis deskriptif adalah statistik yang digunakan untuk menganalisis data dengan cara mendeskripsikan atau menggambarkan data yang telah terkumpul sebagimana adanya tanpa bermaksud membuat kesimpulan yang berlaku untuk umum atau generalisasi."

Dipilinnya metode deskriptif dalam penelitian ini adalah karena permasalahan yang dikaji dalam penelitian ini berkenaan dengan kompetensi profesional guru sosiologi SMA Negeri di Kota Bandung. Oleh karena itu, dalam penelitian ini peneliti ingin mengkaji dan mendeskripsikan bagaimana kompetensi profesional guru sosiologi SMA Negeri di Kota Bandung. Selain itu, peneliti tidak menguji hipotesis melainkan mencari simpulan dari beberapa informasi dan data yang diperoleh mengenai kompetensi profesional guru sosiologi SMA Negri di Kota Bandung.

Partisipan dalam penelitian ini adalah seluruh guru mata pelajaran sosiologi di SMA Negeri di Kota Bandung yang dianggap mampu memberikan informasi tambahan mengenai penelitian yang dilakukan.

Teknik pengumpulan data dalam penelitian ini yaitu menggunakan tes, angket, observasi dan focus group disscussion (FGD). Selanjutnya untuk teknik analis data dalam penelitian ini yaitu dengan pendkoran atau memberikan skor terhadap jawaban yang dianggap benar dan memberikan skor pada setiap pilihan jawaban pada angket.

\section{HASIL DAN PEMBAHASAN}

Guru merupakan jabatan atau profesi yang memerlukan keahlian khusus sebagai guru. Pekerjaan ini tidak bisa dilakukan oleh orang yang tidak memiliki keahlian untuk melakukan kegiatan atau pekerjaan sebagai guru, untuk menjadi guru diperlukan syarat-syarat khusus, sebagai guru yang profesional yang harus menguasai betul seluk-beluk pendidikan dan pengajaran (Usman, 1996, hlm 5).

Untuk menjadi seorang guru diperlukan berbagai keahlian yang menyangkut kemampuannya dalam memahami kependidikan. Sebagai pelaksana dalam pendidikan guru dituntut untuk menguasai berbagai kompetensi untuk menunjang profesinya sebagai seorang guru diantaranya : kompetensi pedagogik, kompetensi profesional, kompetensi sosial dan kompetensi kepribadian. 
Kompetensi profesional tidak akan terlepas dengan profesi guru yang berhubungan langsung dengan siswa. Kompetensi profesional guru terdiri dari Menguasai struktur dan metode keilmuan memiliki implikasi bahwa guru harus menguasai langkah-langkah penelitian dan kajian kritis untuk memperdalam pengetahuan atau materi bidang studi (Suyanto dan Jihad, 2013, hlm. 43).

Penguasaan materi sangat diperlukan dalam proses mengajar seorang guru. Sebagai seorang fasilitator guru yang baik dituntut untuk menguasai apa yang akan disampaikan pada saat pembelajaran, terutama mengenai materi pembelajaran. Persiapan materi pembelajaran sangat perlu dilakukan oleh seorang guru agar saat pelaksanaan pembelajaran guru sudah mengetahui apa yang akan disampaikan pada siswanya, memahami secara utuh materi pembelajaran sehingga pada saat proses pemberian materi berlangsung materi disampaikan secara mendalam dan mempermudah siswa dalam memahami materi.

Penguasaan materi, struktur, konsep, pola pikir keilmuan yang dikuasai dikuasai oleh guru sosiologi dengan persentase paling tinggi yang diperoleh adalah sebesar 55,55\% yang artinya guru sosiologi SMA Negeri Kota Bandung menguasai hakikat keilmuan sosiologi/konsep sosiologi dan objek sosiologi dengan indikator : hakikat sosiologi sebagai, konsep sosiologi, objek sosiologi dan menguasai materi sosiologi secara mendalam dengan materi : status dan peranan, interaksi sosial, metode penelitian sosiologi, kelompok sosial, masyarakat multikultural, lembaga sosial, perubahan sosial budaya dan penyimpangan sosial.

Berdasarkan pengolahan data sesuai dengan yang didapatkan dalam angket dan wawancara bahwa guru sosiologi SMA Negeri di Kota Bandung berasal dari jurusan atau program studi yang berbeda-beda dengan persentase latar belakang pendidikan guru sosiologi SMA Negeri di Kota Bandung yang terbesar bukan berasal dari jurusan sosiologi atau pendidikan sosiologi tetapi berasal dari jurusan pendidikan non sosiologi, alasan mereka mengajar mata pelajaran sosiologi karena pada saat mendaftar menjadi guru belum ada guru yang berasal dari lulusan pendidikan sosiologi dan pada saat itu belum ada program studi khusus pendidikan sosiologi selain itu mata pelajaran sosiologi merupakan pelajaran yang menarik untuk dipelajari oleh semua orang, sehingga minat dari guru tersebut untuk mempelajari sosiologi denga mengikuti pelatihan tertentu ataupun dengan memperlajarinya sendiri dari berbagai sumber selain itu, pendalaman mengenai penguasaan materi dilakukan dengan mengikuti latihan kerja guru (LKG) tingkat kota atau kabupaten dan tingkat provinsi, melalui musyawarah guru mata pelajaran (MGMP) sosiologi sehingga mereka dianggap berkelayakan mengajar mata pelajaran sosiologi. Mansilla dan Gardner (dalam Musfah, 2011, hlm 55) bahwa seorang guru harus memahami pengetahuan tentang ilmu, tujuan, metode dan bentuk materi yang diajarkannya, hal tersebut untuk memberikan pembelajaran yang 
bermakna dan mendalam untuk siswanya.

Salah satu fungsi penguasaan materi oleh guru adalah agar pembelajaran dicapai sesuai dengan tujuannya. Hart (dalam Samana, 1994, hlm 58) mendeskripsikan bahwa seorang guru harus dapat membantu siswa dalam pekerjaan sekolah dan mampu menjelaskan isi pengajarannya secara mendalam dengan menggunakan bahasa yang efektif dan disertai dengan contoh-contoh yang relevan dan siswa mendapat pelajaran dan sesuatu yang bermakna dari gurunya. Sehingga dalam proses belajar mengajar seorang guru harus menguasai secara mendalam materi yang disampaikan untuk membantu siswanya dalam pembelajaran, sesuai dengan tugasnya guru adalah seorang fasilitator.

Penguasaan materi guru sosiologi SMA Negeri di Kota Bandung memang termasuk kedalam kategori yang menguasai materi, tidak ada kesulitan yang signifikan mengenai penguasaan materi sosiologi meskipun mayoritas dari gurunya bukan berasal dari jurusan atau prodi sosiologi. Hal tersebut karena materi sosiologi masih dapat dipelajari dengan mudah apabila memahami konsep dasarnya, kemudian dapat ditambah referensi dari berbagai buku dan dikembangkan dengan mengaitkan fenomena sosial yang terjadi dengan materi.

Persiapan pembelajaran yang dilakukan oleh guru meliputi persiapan materi yang disesuaikan dengan kompetensi dasar dan kompetensi inti yang disusun dalam rencana pelaksanaan pembelajaran. Materi yang dikembangkan guru harus berdasarkan kompetensi dasar dan disesuaikan dengan karakteristik peserta didik.

Penguasaan kompetensi dasar guru sosiologi SMA Negeri di Kota Bandung yang dibagi ke dalam beberapa pernyataan mengenai isi kompetensi dasar, maka hasil terbesar yang diperoleh guru mengenai penguasaan kompetensi dasar mata pelajaran sosiologi adalah sebesar $53,34 \%$. Berdasarkan hasil pengolahan data tersebut maka nilai persentase yang didapat termasuk kedalam kategori menguasai kompetensi dasar. Penguasaan kompetensi dasar guru sosiologi termasuk kedalam kategori yang menguasai, Guru sosiologi SMA Negeri di Kota Bandung menguasai kompetensi dasar juga terlihat dari guru yang selalu mengembangkan materi berdasarkan kompetensi dasar, kompetensi dasar yang dikembangkan menjadi materi disesuaikan dengan kebutuhan siswa kedalam fenomena yang terjadi dalam kehidupan seharihari. Rencana pelaksanaan pembelajaran yang disusun oleh guru sosiologi SMA Negeri di Kota Bandung sudah berlandaskan pada kompetensi dasar yang ada dan kesesuaian terhadap perumusan indikator penguasaan materi yang harus dicapai oleh siswa.

Rumusan Kompetensi Dasar (KD) dikembangkan dengan memperhatikan karakteristik peserta didik, kemampuan awal, serta ciri dari suatu mata pelajaran. Dalam hal ini sebagai guru yang profesional, seorang guru wajib menguasai langkah-langkah dalam penyusunan rancangan pembelajaran karena kompetensi dasar merupakan bahan untuk diperdalamnya materi 
pembelajan. Kompetensi dasar berfungsi sebagai pedoman dalam mengembangkan materi guru agar materi yang dipersiapkan sesuai dengan karakteristik perkembangan siswa dan pembelajaran sesuai dengan tujuan yang hendak dicapai. Oleh karena itu, untuk mencapai pembelajaran yang bermakna maka pembelajaran harus disusun sesuai dengan kompetensi dasar yang hendak dicapai dan telah tersusun secara sistematis sesuai dengan kurikulum yang digunakan.

Materi pembelajaran merupakan faktor yang paling penting dan berpengaruh terhadap keberhasilan siswa dalam menguasai pembelajaran. Mengembangkan materi pembelajaran merupakan hal yang wajib dilakukan oleh guru dalam melakukan persiapan pembelajaran, materi yang akan disampaikan harus sesuai dengan kebutuhan siswanya.

Berdasarkan penelitian mengenai pengembangan materi yang dilakukan oleh guru sosiologi hasil persentase tertinggi yang diperoleh oleh guru sosiologi SMA Negeri di Kota Bandung adalah sebesar 46,67\% dengan demikian pengembangan materi secara kreatif guru sosiologi SMA Negeri di Kota Bandung termasuk kedalam kategori sangat mengembangkan, hal tersebut terlihat dari hasil persentase yang diperoleh oleh guru. Dalam pengembangan materi guru memperhatikan materi yang akan disampaikan sesuai dengan prinsip pemilihan materi yaitu : relevansi atau kesesuaian antara materi dengan kompetensi dasar dan indikator yang disusun untuk mencapai tujuan pembelajaran, konsistensi atau dalam pemilihan dan penggunaan materi, materi yang disampaikan konsisten dengan indikator pencapaian pembelajaran dan sesuai dengan rancangan pembelajaran yang telah disusun, selain itu pemilihan materi harus cukup. Cukup disini berarti materi yang disampaikan tidak terlalu banyak dan tidak terlalu sedikit, materi yang disampaikan harus dapat memberikan seluruh informasi dan mencapai indikator yang telah disusun namun sesuai dengan waktu yang tersedia sehingga siswa dapat lebih mudah untuk memahami materi. Sebelum melaksanakan kegiatan belajarmengajar guru selalu mempersiapkan rancangan pembelajaran, mengkaji materi yang akan disampaikan lebih dalam dan menganalisis kesesuaiannya dengan pencapaian tujuan pembelajaran, menyamakan persepsi dengan guru lain mengenai materi yang kurang relevan dan menambahkan contoh yang akurat untuk memudahkan pemahaman siswa.

Permendiknas No. 16 Tahun 2007 (dalam Kurniasih dan Sani, 2015, hlm 53) bahwa memilih materi disesuaikan dengan Kesesuaian (relevansi), efisien dan efektif, fundamental, luwes, berkesinambungan dan berimbang, memiliki validitas, dan keberartian.

Materi yang disampaikan oleh guru diutamakan efisien sesuai dengan kebutuhan siswa, selain itu point yang paling penting dalam pemilihan dan pengelolaan materi saat ini adalah adanya kesesuaian antara materi pembelajaran dengan keadaan sosial saat ini, terutama dalam mata pelajaran sosiologi. Hal tersebut sejalan dengan pendapat Hamzah (dalam Barnawi dan 
Arifin, 2010, hlm 119) yang mengemukakan bahwa seorang guru yang profesional harus wajib memperhatikan korelasi antara mata pelajaran dengan praktik nyata dalam kehidupan sehari-hari. Guru juga harus dapat membangkitkan minat peserta didik untuk aktif dalam berpikir serta mencari dan menemukan pengetahuan sendiri. Purwanti (dalam Barnawi dan Arifin, 2012, hlm 75) mengemukakan bahwa seorang guru yang profesional juga berperan sebagai motivator yang memberikan dorongan untuk menumbuhkan rasa ingin tahu, sehingga peserta didik memiliki keinginan yang besar untuk belajar, hal tersebut dapat ditempuh dengan menyampaikan materi secara menarik sesuai dengan Permendiknas No. 16 Tahun 2007 (dalam Kurniasih dan Sani, 2015, hlm 53) bahwa materi harus disajikan dengan menarik, materi yang diberikan hendaknya mampu memotivasi peserta didik sehingga peserta didik mempunyai minat untuk mengenali dan mengembangkan keterampilan lebih lanjut dan lebih mendalam.

Materi pembelajaran merupakan komponen yang paling utama dalam sebuah proses belajar-mengajar, karena peserta didik akan mendapatkan pengetahuan melalui materi yang disesuaikan dengan kondisi sosial yang faktual. Pengembangan materi wajib dilakukan oleh guru agar setaip materi yang disampaikan sesuai dengan kebutuhan siswa dan dapat menambah pengetahuan siswa sehingga tujuan dari pembelajaran itu sendiri dapat tercapai sesuai dengan harapan. Selain itu, pengembangan materi penting dilakukan agar pembelajaran dapat terarah sesuai dengan metode pembelajaran yang telah dirumuskan sehingga materi yang disampaikan dapat dikemas sesuai dengan kebutuhan dan pembelajaran tidak menjadi membosankan siswa.

Teknologi dan pengetahuan merupakan dua hal yang tidak dapat dipisahkan dalam kehidupan saat ini. Teknologi saat ini tidak hanya dimanfaatkan untuk melakukan komunikasi saja, untuk mengikuti zaman di era digital dunia pendidikan juga memanfaatkan teknologi dalam pengembangan pendidikan agar pendidikan tidak habis dimakan zaman dikalahkan oleh perkembangan teknologi, oleh karena itu pendidikan dan teknologi harus berjalan beriringan agar pemanfaatan teknologi tidak hanya sebagai alat komunikasi saja tetapi juga sebagai sarana pembelajaran.

Perolehan persentase tertinggi yang didapat oleh guru adalah sebesar 53,33\%. Berdasarkan hasil penelitian bahwa guru sosiologi SMA Negeri di Kota Bandung termasuk ke dalam kategori yang memanfaatkan teknologi, informasi dan komunikasi yaitu dengan memanfaatkan internet sebagai informasi mengenai materi pembelajaran, guru menggunakan internet untuk menambah pengetahuan materi pembelajaran sebagai referensi dan juga sebagai sarana komunikasi dengan siswa. Selain itu guru juga selalu memanfaatkan blog sebagai sarana publikasi materi dan juga sebagai sarana menambah wawasan pengetahuan materi dengan membaca blog dari guru lainnya. Teknologi juga dimanfaatkan oleh guru di dalam kelas 
sebagai sarana penunjang dalam pembelajaran, sehingga memudahkan guru dan siswa dalam proses belajarmengajar seperti menayangkan video pembelajaran dan menyampaikan materi pembelajaran dengan menggunakan power point sehingga materi yang disampaikan dapat dikemas menjadi menarik dan siswa tidak jenuh.

Guru dapat memanfaatkan media sosial, e-mail, blog, internet dan teknologi lainnya untuk menyampaikan materi, sharing materi pembelajaran dengan guru lain dan mengumpulkan materi terbaru dengan memanfaatkan teknologi, sedangkan siswa dapat memanfaatkan teknologi untuk memperoleh informasi yang lebih banyak mengenai materi sosiologi.

Oleh karena itu, guru harus mengembangkan dan memperlajari pengetahuan yang lebih baru mengenai teknologi. Suyanto dan Jihad (2013, hlm. 180) menyampaikan bahwa siswa dan guru harus memiliki akses kepada teknologi digital dan internet dalam kelas, sekolah dan lembaga pendidikan, tersedia materi yang berkualitas dan dukungan sosialbudaya bagi siswa dan guru, guru harus memiliki pengetahuan dan keterampilan dalam menggunakan alat-alat dan sumber-sumber digital untuk membantu siswa mencapai standar pendidikan yang ideal.

\section{SIMPULAN}

Setelah dilakukan penelitan dan pengolahan data kemudian menganalisisnya mengenai kompetensi profesional guru sosiologi SMA Negeri di Kota Bandung, maka diperoleh kesimpulan penelitian sebagai berikut :

$\begin{array}{lr}\text { 1. Penguasaan } & \text { materi, } \\ \text { struktur/konsep/pola pikir }\end{array}$ keilmuan yang mendukung mata pelajaran guru sosiologi SMA Negeri di Kota Bandung yang terdiri dari penguasaan hakikat sosiologi sebagai ilmu, konsep sosiologi, objek sosiologi dan penguasaan materi sosiologi secara mendalam termasuk kedalam kategori menguasai materi dengan baik, hal ini dapat dilihat dari skor dan analisis persentase yang diperoleh guru dari penelitian yang didapat melalui tes yang diberikan kepada guru sosiologi SMA Negeri di Kota Bandung.

2. Pemahaman dan penguasaan terhadap kompetensi dasar (KD) guru sosiologi SMA Negeri di Kota Bandung yang terdiri dari sejumlah kompetensi dasar sebagai bahan dasar pengembangan materi pembelajaran berada pada kemampuan menguasai kompetensi dasar dengan baik sebagai landasan untuk mengembangkan materi, hal tersebut dapat dilihat dari skor dan analisis persentase yang diperoleh guru dari penelitian yang didapat melalui kuisioner yang diberikan kepada guru sosiologi SMA Negeri di Kota Bandung.

3. Pengembangan materi secara kreatif oleh guru sosiologi SMA Negeri di Kota Bandung yang 
terdiri dari pemilihan materi yang sesuai dengan tingkat dan kebutuhan siswa dari materi sosiologi dan pengelolaan materi sosiologi dari mulai pemilihan tema sampai dengan pengembangan materi berada pada kemampuan yang sangat mengembangkan materi secara kreatif, hal tersebut dapat dilihat dari skor dan analisis persentase yang diperoleh guru dari penelitian yang didapat melalui kuisioner yang diberikan kepada guru sosiologi SMA Negeri di Kota Bandung.

4. Pemanfaatan teknologi, informasi dan komunikasi sebagai sarana untuk mengembangkan materi, penyampaian dan pertukaran informasi oleh guru sosiologi SMA Negeri di Kota Bandung berada pada kemampuan yang sangat memanfaatkan teknologi, informasi dan komunikasi, hal tersebut dapat dilihat dari skor dan analisis persentase yang diperoleh guru dari penelitian yang didapat melalui kuisioner yang diberikan kepada guru sosiologi SMA Negeri di Kota Bandung.

\section{DAFTAR PUSTAKA}

Barnawi dan Arifin, Mohammad. (2012). Etika dan Profesi Kependidikan. Yogyakarta: ArRuz Media.

Kurniasih dan Sani. (2015). Sukses

Uji Kompetensi Guru (UKG).

Surabaya: Kata Pena.

Musfah, Jejen. (2011). Peningkatan Kompetensi Guru. Jakarta: Kencana Prenada Media Group. Samana, A. (1994). Profesionalisme Keguruan. Yogyakarta: Kanisius.

Sanjaya, Wina. (2006). Strategi Pembelajaran Berorientasi Standar Proses Pendidikan. Jakarta: Kencana Prenada Media Group.

Sugiyono. (2013). Metode Penelitian Pendidikan. Bandung: Alfabeta Suyanto dan Jihad. (2014). Menjadi Guru Profesonal : Strstegi Meningkatkan Kualifikasi dan Kualitas Guru di Era Global. Bandung: Erlangga.

Usman, Mohamad Uzer. (1996). Menjadi Guru Profesional. Bandung: Remaja Rosdakarya. 